\title{
Knowledge, attitude and practices concerning HIVIAIDS among Hossana CTE student teachers, SNNPR region, Ethiopia
}

\begin{abstract}
The main purpose of this research was to examine the knowledge, attitudes and practices of students of Hossana CTE regarding HIV/AIDS. To achieve this, a cross-sectional research design was employed. 157 students, 97 males and 60 females were drawn randomly from the three year levels. The participants' age range was from17-26. Data was collected using questionnaire and scales. The collected data were analyzed in descriptive and inferential statistics namely frequencies, percentages, t-test and one way ANOVA. Thus, the study revealed that student's common sources of information to know about HIV/AIDS were health professionals, Television, Radio, Pamphlets, Teachers and Newspapers respectively; though significant number of students had different misconceptions and knowledge deficiencies with regard to routes of transmissions and ways of preventions of HIV/AIDS Likewise, there was generally undesirable attitude among students towards HIV/AIDS and PLWHAs. With regard to their practice, the study figured out that students had risky sexual practices (early sexual experience, less use of condoms, abundant sharing of sharp materials). Furthermore, the t-test result revealed that no statistically significant gender difference was found in knowledge and attitude of participants except for the practice. In the same vein, no statistically significant difference was observed in knowledge, attitude and practice among year I, year II and year III students. Finally, the study recommended that the need to address the knowledge, attitude and practice to mitigate gaps observed through designing and implementing relevant intervention programs.
\end{abstract}

Keywords: knowledge, attitude, practice, college students
Volume 3 Issue 3 - 2019

\section{Endalkachew Admassu, ' Yitades Tesfaye, ${ }^{2}$ Mulugeta Dadi²}

'Department of Psychology, Kotebe Metropolitan University, Ethiopia

${ }^{2}$ Department of Preschool Education, Kotebe Metropolitan University, Ethiopia

Correspondence: Yitades Tesfaye, Department of Preschool Education, Kotebe Metropolitan University, Ethiopia, Email tyitades@yahoo.com

Received: April 13, 2019 | Published: May 30, 2019

\section{Introduction}

Since the first HIV case was reported in USA, the epidemic has spread worldwide in alarming rate and currently reached amongst the biggest health threat specially for developing nations. Although enormous progress in prolonging and improving the quality of life of those infected with Human Immuno deficiency Virus (HIV) have been made, the world still has neither a cure for, nor a vaccine to prevent this disease. Perhaps most importantly, it has become increasingly clear that preventing the transmission and the acquisition of HIV must focus upon behavior and behavioral changes. AIDS is first and foremost a consequence of behavior: it is not who one is, but what one does, that determines whether he or she will be exposed to HIV. ${ }^{1}$

According to UNAIDS ${ }^{2}$ world report, HIV prevalence is leveling off and there is a fall in the number of new infections globally. Although HIV/AIDS is showing a decline, it remains one of the leading obstacles to health and development for poor countries. There are still a huge number of people infected and affected by HIV. In 2007, around 33.4 million people were estimated to be living with HIV globally, of which about 2.7 million people are newly infected and around 2.0 million lost their lives due to AIDS in the same year. In fact, Sub-Saharan Africa accounts for 22.4 million infections, which is about $67 \%$ of the total HIV burden. The number of people estimated to acquire new infections is around 1.9 million accounting for $68 \%$ of the total number of new infections (ibid). The report also disclosed that HIV/AIDS has become the leading cause of death in the region. Ethiopia is one of the Sub-Saharan African countries, which is most severely affected by the HIV/AIDS pandemic. The first case of HIV in Ethiopia was reported in 1984. Since then, HIV/AIDS become a major public health concern in the country leading the Government of Ethiopia to declare a public health emergency in 2002. In 2007, the estimated adult HIV/AIDS prevalence in Ethiopia was 2.1 percent. Again National projections estimate approximately 1.1 million Ethiopians are living with HIV and prevalence will increase slightly to 2.3 percent by 2009 . Although the epidemic is currently stable, HIV/AIDS remains a major development challenge for the nation. Poverty, food shortages and other socio-economic factors amplify the impact of the epidemic.

Currently, the national adult prevalence rate is estimated at 2.3 percent and an estimated number of 1.2 million people are living with HIV/AIDS. ${ }^{4}$ An estimated 67,000 lost their lives due to AIDS at the end of 2007 (ibid). In Ethiopia, higher risk sex (i.e. sex without adequate protection) among both women and men are most prevalent among those living in urban areas, among those with a secondary or higher education are those in the highest quartile. Although there are some encouraging signs, surveillance results indicate that the epidemic is still progressing though at a slower rate than previously predicted. According to the second round HIV/AIDS Behavioral Surveillance Survey in Ethiopia, it was found out that around 9.9 percent of the in-school youth (14.6\% of males and $5.3 \%$ of females) had sexual experience. ${ }^{5}$ The mean and medium age of sexual debut among youth was 16 years. Only that 41.8 percent of in school youth who had sex with non-commercial partners reported consistent use of condoms.

Demographic health surveys of many countries have prevailed that adolescents nowadays are experienced puberty at younger age than the previous generation. As result, they are involved in early initiation of sexual intercourse; most of it is being unsafe, unplanned and exposing them to unwanted pregnancy, abortion and sexually transmitted diseases including HIV/AIDS. ${ }^{6}$ Risk behaviors like unprotected sex, 
multi sexual partnership, no or inconsistence use of condoms and drug abuse are extremely determinate to health of adolescents and young adults putting them at high risk to HIV/AIDS and other Sexual transmitted diseases. ${ }^{6}$ Over half of all new infections worldwide were among young people between the ages of 15 and 24. Every day, 6,000 young people become infected with HIV- more than five every minute. This shows that HIV/AIDS is affecting young members of the societies especially adolescents between the age of 17 to 26 who are vulnerable and at risk of the disease. It is also estimated that most college and university students lie within the age group of 18 to 24 years. ${ }^{5}$ A number of studies have showed that AIDS has progressively been on the increase and constitutes a big problem among college and university students, although the extent of the problem is relatively unknown. ${ }^{7-11}$

Evidences showed that most sexual risk behaviors among college and university students might have been acquired through period of campus life. ${ }^{10}$ This may be due to the life of independence, away from parental control, that often characterizes such setting (ibid) College and university students are often viewed as being at high risk for HIV infection due to their propensity to engage in exploratory behavior and their needs for peer social approval and false sense of non-vulnerability. ${ }^{12}$ In general, due to the very nature of the students; because of their age, ambition to experience new events, and other factors described in the few paragraphs above, students of higher education (Hossana College of Teacher Education in this context) are likely to be at risk of HIV/AIDS. Similarly, the spread of HIV/ AIDS in any community is in part determined by the knowledge, attitude towards sexuality of its members and by their actual sexual practices. So before formulating any kind of intervention program for the prevention of the spread of HIV/AIDS, it is critical to obtain information about the prevalent knowledge, attitude and practice (KAP) regarding HIV/AIDS, in the target community. Several studies on KAP regarding HIV/AIDS have been reported from different parts of Ethiopia. However; most of them didn't consider higher education students as their target population. Besides to that, there are no studies on KAP regarding HIV/AIDS among students of Hosanna College of Teacher Education. This shows that there need to be a continuous assessment of KAP regarding HIV/AIDS in the students of the college to implement different intervention programs. Therefore, this research intends to assess HIV/AIDS related knowledge, attitudes and practices among the student teacher's of Hosanna College of Teachers Education.

In an attempt to achieve the purpose of the research, the following research questions were formulated for in-depth investigation.

a. How do student-teachers of Hossana CTE perceive the current situational status of HIV/AIDS in Ethiopia?

b. Which sources of information are most commonly utilized by student- teachers regarding HIV/AIDS?

c. Do student teachers of Hossana CTE have enough knowledge as far as HIV/AIDS and related issues concerned?

d. Do student-teachers of Hossana CTE have desirable and tolerable attitudes towards HIV and PLWHAs respectively?

e. Do student-teachers of Hossana CTE have appropriate and safer practices which prevent them from HIV infection?

f. Is there statistically significant difference in Knowledge, attitude and practice regarding HIV/AIDS by demographic variables (gender and year of staying in college)

\section{Methodology}

\section{Research design}

This study used a cross-sectional survey research design. As mentioned earlier the purpose of this study was assessing HIV/AIDS related knowledge, attitude and practices of teacher-trainees found at Hossana CTE.

\section{Research location}

The study carried out at Hossana CTE. Hossana CTE is found in Hossana town of Hadiya Zone, SNNPR. The researchers chose the study site based on the rational that the college's Anti-HIV/AIDS Mainstreaming office wanted to know the current status concerning the student-teachers Knowledge, attitude and practices of HIV/AIDS.

\section{Population}

The accessible population for this study was all student-teachers of Hossana CTE (from year I-III) of both males and females who were pursuing their education/training in the academic year of 2016. The data received from the college's registrar office revealed that in the II semester of 2016 academic calendar, there were 1678 trainees. Out of which 1091 were males and 587 were females.

\section{Samples and sampling}

Participants were selected using stratified proportional random sampling technique. In so doing, Student-teachers were stratified based on their year of study. Then from the three years of study, equal number of participants ( 60 from first year, 60 from second year and 60 from third year) were randomly selected through lottery method.

\section{Instruments}

Demographic questionnaire, situation of HIV/AIDS scale $(\mathrm{N}=1)$, sources of information questionnaire $(\mathrm{N}=13)$, HIV/AIDS knowledge questionnaire ( $\mathrm{N}=18)$, the AIDS attitude scale $(\mathrm{N}=13)$ and HIV/AIDS related practice questionnaire $(\mathrm{N}=4)$ were used. Questionnaires related to knowledge, attitude and practice were adopted from Marianne ${ }^{13}$ and then translated from English to Amharic. The questionnaires were translated back to English in order to ensure consistency from the original English version of the questionnaire. ${ }^{13}$ In order to ensure face and content validity; the questionnaires were given to the college's Anti-HIV/AIDS Mainstreaming officers. They agreed on the scales appropriate comprehension and proper use of the Amharic language (Appendix).

\section{The demographic questionnaire}

The demographic questionnaire included data on sex, age, year of study and relationship status

\section{Situation of HIVIAIDS scale}

Situation of HIV/AIDS scale was used to know the perception of participants concerning the current situation of HIV/AIDS in Ethiopia. One indicates HIV/AIDS is not a problem at all and five indicates HIV/AIDS is a very serious threat to Ethiopia.

\section{Sources of information questionnaire}

Different sources of information were outlined and ticked by respondents in order to identify their major supplies of information regarding HIV/AIDS. 


\section{HIVIAIDS knowledge questionnaire}

The HIV knowledge questionnaire $(\mathrm{N}=18)$ was originally developed by and adopted from Marianne. ${ }^{13}$ It was used to measure knowledge of HIV transmission. It was a self-administered questionnaire, which has 18 items and tests the knowledge of transmission, prevention and treatment of HIV/AIDS. The questionnaire was presented in "True", "False", and "Not sure" statements, which are tallied up as a crude score on the overall correct answers identified. Thus, a higher score suggests greater knowledge and conversely a lower score would indicate a lower general knowledge related to HIV/AIDS.

\section{HIVIAIDS attitude scale}

HIV/AIDS Attitude Scale was prepared by the researchers using ideas from different literatures and the pilot test result confirmed reliable and validated. It has 13 item scales which measures the subscales of empathy, avoidance and misconceptions regarding HIV/ AIDS. The scale is based on a five point Likert scale varying from one (strongly disagree) to five (strongly agree).

\section{HIVIAIDS practice questionnaire}

In order to know whether the participants are at risk of being infected with HIV, a 4 item questionnaire was constructed by the researchers. Items included treats issues like sexual exposure, condom use, habit of sharing sharp materials and preventive mechanisms utilized.

\section{Procedures of administration and scoring}

Administration: Participants were contacted during class hour in person and given details about the purpose of the study. Then, verbal instructions describing the procedure how to fill the questionnaire and scales were given. The questionnaire booklet was distributed after verbal consent was secured. Respondents were informed that they could withdraw from the study at any point. The questionnaires were completed under supervision during normal class periods. The researchers and an assistant were there to ensure confidentiality and independent responding. Finally, the booklet was collected and participants were thanked for their time and kind cooperation.

Methods of data analysis: Analyses of data were made with the help of Statistical Package for Social Sciences version 15.0 for windows. Statistical computations such as frequencies, percentages, mean score, T-test and ANOVA.

\section{Results}

\section{Demographic characteristics of participants}

As can be observed from Table 1 above, the total sample size collected were 157 respondents, 97(61.8\%) males and 60 (38.2\%) females. Moreover, the participants in this study ranged in age from 17-25. As expected, almost all participants were found to be in the age of high vulnerability for HIV infections. The samples selected for this study came from three different year of study. Thus, more than one third of the respondents were first year 57(36.3\%) while $54(34.4 \%)$ were year II and the rest $46(29.3 \%)$ of them drawn from year III or prospective teachers. As for respondents relationship status, 101(67.6\%) were not engaged in heterosexual relationship while 51(32.4\%) were engaged in heterosexual relationship.
Table I Participants background information

\begin{tabular}{llll}
\hline Variables & & f & $\%$ \\
\hline Sex & Male & 97 & 61.8 \\
& Female & 60 & 38.2 \\
& Total & 157 & 100 \\
Age & $17-20$ & 109 & 69.4 \\
& $21-25$ & 48 & 30.6 \\
Year of study & One & 157 & 100 \\
& Two & 57 & 36.3 \\
& Three & 54 & 34.4 \\
& Total & 46 & 29.3 \\
& Engaged & 51 & 32.4 \\
& Not engaged & 101 & 67.6 \\
& Total & 157 & 100 \\
\hline
\end{tabular}

\section{Perception about the status of HIVIAIDS in Ethiopia}

One of the objectives of this research was identifying how the respondents view the situational status of HIV/AIDS in Ethiopia. As Table 2 above depicted, more than three-fourth 123(78.3\%) of the respondents rated the situation as "serious" and "very serious" reflecting a high level of concern and fear concerning Ethiopia's HIV/ AIDS problems. While $16(10.2 \%)$ of the respondents revealed that they do not know the current status of the epidemic in the country. Besides, 15(9.6\%) of the participants perceived HIV/AIDS as insignificant problem of the nation and also already under control.

Table 2 Respondents perception regarding situation of HIVIAIDS in Ethiopia

\begin{tabular}{lccc}
\hline Item & f & $\%$ & Remark \\
\hline How do you rate the current situation of HIVIAIDS in Ethiopia? \\
$\begin{array}{l}\text { Not a problem } \\
\text { A small problem, but under } \\
\text { control }\end{array}$ & 3 & 1.9 \\
A serious problem & 15 & 9.6 \\
A very serious problem & 32 & 20.4 \\
Uncertain/don't know & 91 & 57.9 \\
& 16 & 10.2 \\
Total & 157 & 100 \\
\hline
\end{tabular}

\section{Major sources for HIVIAIDS knowledge}

Table 3 presents the major sources of knowledge utilized by respondents regarding HIV/AIDS. The study revealed that respondents felt that their major sources to get knowledge about HIV/AIDS were health professionals $(79.0 \%)$, followed by Television (69.4\%), Radio (64.3), pamphlets about HIV/AIDS (58.6\%), teachers (51.0\%) and newspaper(46.5\%). It is also interesting to note that just (22.9\%) get information from family and friends. 
Table 3 Respondents major sources for HIVIAIDS knowledge

\begin{tabular}{llll}
\hline No. & Sources & f & $\%$ \\
\hline I & Health professionals & 124 & 79 \\
2 & Television & 109 & 69.4 \\
3 & Radio & 101 & 64.3 \\
4 & Pamphlets about HIVAIDS & 92 & 58.6 \\
5 & Teachers & 80 & 51 \\
6 & Newspapers & 73 & 46.5 \\
7 & Magazines & 66 & 42 \\
8 & Religious organizations & 56 & 35.7 \\
9 & Sex partners & 41 & 26.8 \\
10 & Neighbors/community & 37 & 23.6 \\
11 & Family/friends & 36 & 22.9 \\
12 & Internets & 29 & 18.5 \\
13 & Relatives & 18 & 11.5 \\
\hline
\end{tabular}

\section{Knowledge concerning HIVIAIDS}

Table 4 above reveals respondents knowledge about HIV/AIDS The HIV knowledge Questionnaire consisted 18 true false items. Each correct item obtains a score of 1 , while incorrect or not sure responses were coded as 0 .

Table 4 Respondents' knowledge concerning HIVIAIDS

\begin{tabular}{|c|c|c|c|c|c|c|}
\hline \multicolumn{2}{|c|}{ Items } & \multirow[t]{2}{*}{$\begin{array}{l}\text { Correct } \\
\text { Response }\end{array}$} & \multicolumn{2}{|c|}{$\begin{array}{l}\text { Knowled- } \\
\text { geable }\end{array}$} & \multicolumn{2}{|c|}{$\begin{array}{l}\text { Not } \\
\text { Knowled- } \\
\text { geable }\end{array}$} \\
\hline & & & f & $\%$ & f & $\%$ \\
\hline I & HIV is caused by bacteria & FALSE & 144 & 91.7 & 13 & 8.3 \\
\hline 2 & HIV \& AIDS are the same & FALSE & 121 & 77.1 & 36 & 22.9 \\
\hline 3 & $\begin{array}{l}\text { Consistent and correct } \\
\text { usage of condom prevents } \\
\text { HIV }\end{array}$ & TRUE & 101 & 64.3 & 56 & 35.7 \\
\hline 4 & AIDS has no cure & TRUE & 136 & 86.6 & 21 & 13.4 \\
\hline 5 & $\begin{array}{l}\text { Mosquito bite transmits } \\
\text { HIV }\end{array}$ & FALSE & $13 \mid$ & 83.4 & 26 & 16.6 \\
\hline 6 & $\begin{array}{l}\text { HIV spreads through saliva } \\
\text { or sweat }\end{array}$ & FALSE & 125 & 79.6 & 32 & 20.4 \\
\hline 7 & $\begin{array}{l}\text { Being faithful to a single } \\
\text { sexual partner can } \\
\text { prevent from HIV }\end{array}$ & TRUE & 134 & 85.3 & 23 & 14.7 \\
\hline 8 & $\begin{array}{l}\text { Abstinence from sexual } \\
\text { intercourse can prevent } \\
\text { from HIV }\end{array}$ & TRUE & 129 & 82.1 & 28 & 17.9 \\
\hline 9 & $\begin{array}{l}\text { HIV infected person can } \\
\text { be identified through } \\
\text { physical appearance }\end{array}$ & FALSE & 80 & 50.9 & 77 & 49.1 \\
\hline 10 & $\begin{array}{l}\text { HIV do not transmit } \\
\text { through coughing \& } \\
\text { sneezing } \\
\text { Taking shower prevents }\end{array}$ & TRUE & 136 & 86.6 & 21 & 13.4 \\
\hline 11 & $\begin{array}{l}\text { from being infected with } \\
\text { HIV } \\
\text { Symptoms of HIV }\end{array}$ & FALSE & $13 \mid$ & 83.4 & 26 & 16.6 \\
\hline 12 & $\begin{array}{l}\text { infection are visible within } \\
\text { days of infection }\end{array}$ & FALSE & 128 & 81.5 & 29 & 18.5 \\
\hline
\end{tabular}

Table Continued

\begin{tabular}{|c|c|c|c|c|c|c|}
\hline \multicolumn{2}{|c|}{ Items } & \multirow[t]{2}{*}{$\begin{array}{l}\text { Correct } \\
\text { Response }\end{array}$} & \multicolumn{2}{|c|}{$\begin{array}{l}\text { Knowled- } \\
\text { geable }\end{array}$} & \multicolumn{2}{|c|}{$\begin{array}{l}\text { Not } \\
\text { Knowled- } \\
\text { geable }\end{array}$} \\
\hline & & & f & $\%$ & f & $\%$ \\
\hline 13 & $\begin{array}{l}\text { All HIV infected mothers } \\
\text { give birth to HIV infected } \\
\text { child }\end{array}$ & FALSE & 125 & 79.6 & 32 & 20.4 \\
\hline 14 & There is Vaccine for HIV & FALSE & 118 & 75.1 & 39 & 24.9 \\
\hline 15 & $\begin{array}{l}\text { Multiple sexual partners } \\
\text { increase the risk of HIV } \\
\text { infection }\end{array}$ & TRUE & 123 & 78.3 & 34 & 21.7 \\
\hline 16 & $\begin{array}{l}\text { Undergoing HIV test after } \\
\text { a week of infection shows } \\
\text { the exact result }\end{array}$ & FALSE & 106 & 67.5 & 51 & 32.5 \\
\hline 17 & $\begin{array}{l}\text { Sharing swimming pool } \\
\text { with HIV infected person } \\
\text { transmits the virus }\end{array}$ & FALSE & 120 & 76.4 & 37 & 23.6 \\
\hline \multirow[t]{2}{*}{18} & $\begin{array}{l}\text { Use of double condoms } \\
\text { reduces chance of HIV } \\
\text { infection }\end{array}$ & FALSE & 73 & 46.4 & 84 & 53.6 \\
\hline & *Mean & $* * S D 2.47$ & & & & \\
\hline
\end{tabular}

Generally, a large proportion of respondents (91.7\%) knew that HIV is a virus not a bacterium. However, significant number of students $(22.1 \%)$ could not able to differentiate HIV and AIDS. Likewise, around $13.4 \%$ of the respondents claimed that AIDS has cure. There was also huge misconception about condom's preventive ability among the students, as can be viewed from the above result. It was shown that $56(35.7 \%)$ of the students indicated that consistent and correct use of condom cannot prevent HIV. While the majority of respondents $131(83.4 \%)$ had clear understanding that there is no risk of getting HIV by mosquito bite, significant number of students 26 $(16.6 \%)$ misconceived the issue. $20.4 \%$ of the respondents responded incorrectly for (Q6), "HIV spreads through saliva or sweat"; while 14.7 of them still did not know being faithful to a single sexual partner can prevent from HIV. A very striking finding was that almost half of the respondents $49.1 \%$ claimed that HIV infected person can be identified through physical appearance. On the other hand, $13.4 \%$ of the students felt that HIV transmits through coughing \& sneezing. Students were asked to indicate whether taking shower or washing genital areas immediately after sexual intercourse prevents from being infected with HIV; the result clearly manifested that $16.6 \%$ of them reported as a correct action. For $18.5 \%$ of the students, symptoms of HIV infection are visible within days of infection while there is Vaccine for HIV for those $24.9 \%$ of the study sample.

Misconception was also detected on $21.7 \%$ of students with regard to multiple sexual partners increase the risk of HIV infection. It was also worth to mention that there were considerable numbers of individuals $32.5 \%$ who consider the possibility of HIV detection in blood test just after a week of infection. It has been found that $23.6 \%$ of the respondents had an understanding that Sharing swimming pool with HIV infected person transmits the virus. Finally, more than half of the respondents answer revealed that $53.6 \%$ of them misconceived that use of double condoms reduces chance of HIV infection.

\section{Attitudes towards HIVIAIDS}

About $20 \%$ of the respondents associated HIV/AIDS with immoral life styles and still some recommended isolation of AIDS patients for the safety of others. Although their number is quite limited around $11 \%$ of the respondents felt that AIDS can be treated by traditional 
medicines. On the other hand, more than half of the respondents $51.6 \%$ felt that the problems created by HIV/AIDS is exaggerated and around one tenth of the sample 16(10.2\%) believed that Shaking hands with PLWHAs will have problems.

Considerable number of respondents expressed that $44(28.1 \%)$ they were uncomfortable to work with PLWHAs since they believe that it will have problems. In the same vein, $38(24.3 \%)$ of students those included in the study were unwilling to Share a living room as well as to eat with PLWHAs because they felt that that may expose them for HIV. When looking respondents' willingness of sharing of latrine, around $12 \%$ of them disagreed while $21.7 \%$ did not want to receive services from and $17.2 \%$ of them were totally unwilling to provide care and support for PLWHAs. More than two fifth of the respondents $42.1 \%$ felt that those People who are infected with HIV through sexual intercourse have got their price.

\section{Practices related to HIVIAIDS}

To identify respondent's sexual practices and the preventive measures they utilized, frequency and percentage were computed. So table 6 above revealed that, questions concerning whether participants have made sexual intercourse so far or not, $64.3 \%$ of the respondents reported that they have never made sexual intercourse with opposite sex, on the other hand, $35.7 \%$ of them reported that they have made sexual intercourse with opposite sex. Similarly, out of those participants who have made sexual intercourse with opposite sex only $37.5 \%$ of them were used condoms during the intercourse whereas $60.7 \%$ of them did not use condom during the intercourse. Concerning participants' behavioral trend of sharing of sharp materials with other individuals that will expose them for HIV/AIDS, the same table above also showed that only $57.3 \%$ of the participants replied that they had never shared sharp materials with other individuals. On the other hand, $36.9 \%$ of the participants reported that they shared sharp materials with other individuals.

Table 5 Respondents' attitudes about HIV/AIDS

\begin{tabular}{|c|c|c|c|c|c|c|}
\hline \multirow[t]{2}{*}{ No. } & \multirow[t]{2}{*}{ Items } & \multirow[t]{2}{*}{$\begin{array}{l}\text { Correct } \\
\text { Response }\end{array}$} & \multicolumn{2}{|c|}{$\begin{array}{l}\text { Desirable } \\
\text { Attitude }\end{array}$} & \multicolumn{2}{|c|}{$\begin{array}{l}\text { Undesirable } \\
\text { Attitude }\end{array}$} \\
\hline & & & f & $\%$ & f & $\%$ \\
\hline I & Only those people who lead immoral lives will get HIV & Disagree & 125 & 79.6 & 32 & 20.4 \\
\hline 2 & AIDS patients should be isolated for the safety of others & Disagree & 139 & 88.5 & 18 & 11.5 \\
\hline 3 & AIDS can be treated by traditional medicines & Disagree & 140 & 89.1 & 17 & 10.9 \\
\hline 4 & The problems created by HIV/AIDS is exaggerated & Disagree & 76 & 48.4 & 81 & 51.6 \\
\hline 5 & Shaking hands with PLWHAs will have problems & Disagree & $|4|$ & 89.8 & 16 & 10.2 \\
\hline 6 & Working with PLWHAs victims will not have problem & Agree & 113 & 71.9 & 44 & 28.1 \\
\hline 7 & Sharing room with PLWHAs will have problems & Disagree & 119 & 75.7 & 38 & 24.3 \\
\hline 8 & Eating with PLWHAs will have problems & Disagree & 119 & 75.7 & 38 & 24.3 \\
\hline 9 & Sharing latrine with PLWHAs will have problems & Disagree & 138 & 87.8 & 19 & 12.2 \\
\hline 10 & Receiving services from PLWHAs will have problems & Disagree & 123 & 78.3 & 34 & 21.7 \\
\hline II & $\begin{array}{l}\text { Giving care and support for PLWHAs will not have } \\
\text { problems }\end{array}$ & Agree & 130 & 82.8 & 27 & 17.2 \\
\hline 12 & Checking ones status of HIV is not as such important & Disagree & $14 \mid$ & 89.8 & 16 & 10.2 \\
\hline 13 & $\begin{array}{l}\text { People who are infected with HIV through sexual } \\
\text { intercourse have got their price }\end{array}$ & Disagree & 91 & 57.9 & 66 & 42.1 \\
\hline *Mean & 40.76 & & & **SD 5.40 & & \\
\hline
\end{tabular}

Finally concerning the preferred preventive measure participants endorsed with, the result of table 6 portrayed that, $52.2 \%$ of the participants endorsed in abstinence, $39.5 \%$ of them endorsed in a one to one faithful relationship, whereas $8.3 \%$ of the participants proclaimed regular use of condoms as their preferred preventive mechanism.

\section{Relationship between gender \& kap related to HIVI AIDS}

An independent sample t-test was conducted in order to ascertain whether or not there was a significant mean difference in the knowledge, attitude, and sexual practice scores between male and female students. So, as table 7 above revealed that there was no a statistically significant gender difference $(t=0.987, p>0.05)$ in knowledge scores of male and female participants. Similarly, the result of the same table above indicated that a statistically significant gender difference was not found in attitude scores of male and female participants $(\mathrm{t}=0.026, \mathrm{p}>0.05)$.

Contrary to that, table 7 above depicted that a statistically significant gender difference was found in the sexual practice scores of male and female participants $(\mathrm{t}=1.861, \mathrm{p}<0.05)$. Which is male students (Mean=0.41) received significantly higher scores than 
female students $($ Mean $=0.27)$. This means that male students were highly involved in sexual practice than their female counterparts.

Table 6 Respondents' distribution according to practices that exposes HIV/ AIDS \& preventive measures

\begin{tabular}{|c|c|c|c|}
\hline Variables & & f & $\%$ \\
\hline \multirow[t]{2}{*}{ Sexual Exposure } & Yes & 56 & 35.7 \\
\hline & No & 101 & 64.3 \\
\hline Total & & 157 & 100 \\
\hline \multirow[t]{3}{*}{ Condom Use } & Yes & 21 & 37.5 \\
\hline & No & 34 & 60.7 \\
\hline & Missing & 1 & 1.8 \\
\hline Total & & 56 & 100 \\
\hline \multirow[t]{3}{*}{$\begin{array}{l}\text { Sharing of Sharp } \\
\text { Materials }\end{array}$} & Yes & 58 & 36.9 \\
\hline & No & 90 & 57.3 \\
\hline & Missing & 9 & 5.7 \\
\hline Total & & 157 & 100 \\
\hline \multirow[t]{4}{*}{$\begin{array}{l}\text { Preventive } \\
\text { Mechanism }\end{array}$} & Abstinence........... & 82 & 52.2 \\
\hline & $\begin{array}{l}\text { Be faithful to one } \\
\text { partner......... }\end{array}$ & 62 & 39.5 \\
\hline & $\begin{array}{l}\text { Consistent use of } \\
\text { condom................... }\end{array}$ & 13 & 8.3 \\
\hline & Total & 157 & 100 \\
\hline *Mean & 0.36 & \multicolumn{2}{|c|}{ **SD 0.48} \\
\hline
\end{tabular}

Table 7 Independent Sample T -Test of gender differences in knowledge, attitude and practice related to HIV AIDS

\begin{tabular}{lllllll}
\hline $\begin{array}{l}\text { Dependent } \\
\text { variables }\end{array}$ & Sex & N & Mean & SD & Df & t-value \\
\hline Knowledge & Male & 97 & 13.92 & 2.473 & 155 & 0.987 \\
& Female & 60 & 13.52 & 2.474 & & \\
Attitude & Male & 97 & 40.77 & 5.589 & 155 & 0.026 \\
& Female & 60 & 40.75 & 5.128 & & \\
Practice & Male & 97 & 0.41 & 0.495 & 155 & $1.86 I^{*}$ \\
& Female & 60 & 0.27 & 0.446 & &
\end{tabular}

$* P<.05$

\section{Relationship among kap related to HIVIAIDS \& year of study}

To investigate the influence of year of study on knowledge, attitude, and sexual practice scores of participants, a one way ANOVA was computed for each. A close examination of table 8 portrayed that there were no statistically significant year of study differences in the knowledge, attitude, and sexual practice of participants among $1^{\text {st }}$, $2^{\text {nd }}$, and $3^{\text {rd }}$ year students, i.e.., $F(2,154)=2.344, p>0.05$, F $(2,154)$ $=2.448, \mathrm{P}>0.05$, and $\mathrm{F}(2,154)=0.216 \mathrm{p}>.05$ respectively.
Table 8 Summary of one way ANOVA for the knowledge, attitude and practice of participants

\begin{tabular}{llllll}
\hline $\begin{array}{l}\text { Dependent } \\
\text { variables }\end{array}$ & $\begin{array}{l}\text { Sources of } \\
\text { variations }\end{array}$ & $\begin{array}{l}\text { Sum of } \\
\text { squares }\end{array}$ & Df & $\begin{array}{l}\text { Mean } \\
\text { square }\end{array}$ & $\mathbf{F}$ \\
\hline Knowledge & Between groups & 28.191 & 2 & 14.096 & 2.344 \\
& Within groups & 926.089 & 154 & 6.014 & \\
& Total & 954.28 & 156 & & \\
Attitude & Between groups & 140.191 & 2 & 70.096 & 2.448 \\
& Within groups & 4410.089 & 154 & 28.637 & \\
& Total & 4550.28 & 156 & & \\
Practice & Between groups & 0.101 & 2 & 0.05 & 0.216 \\
& Within groups & 35.924 & 154 & 0.233 & \\
& Total & 36.025 & 156 & & \\
\hline
\end{tabular}

\section{Discussion}

In this sub section of the study report, the findings of the present investigation are discussed in light of previous studies and possible explanations.

\section{Perception of students about the current status of HIVIAIDS in Ethiopia}

A very important finding of the present study was that $78.3 \%$ of students perceived the current status/situation of HIV/AIDS in Ethiopia as serious and very serious problem for their country. This finding is in harmony with previously conducted researches worldwide. ${ }^{14}$ Similar research conducted in china revealed that majority of university students perceived HIV/AIDS was a huge health concern for their country. This may imply that the youth group is particularly concerned with the spread of HIV epidemic though this does not an indication of their actual behaviors.

\section{Major sources of information about HIVIAIDS}

With regard to the major sources of information students utilize about HIV/AIDS, the present research clearly revealed that health professionals $(79.0 \%)$, television $(69.4 \%)$, radio $(64.3 \%)$, pamphlets about HIV/AIDS (58.6\%), teachers $(51.0 \%$ and newspaper $(46.5 \%)$ were found to be among the most accessible sources of information students utilize for their need concerning HIV/AIDS. This particular finding, Health professionals and teachers, as major sources of information was in contrary to previous research finding. ${ }^{14}$ However, results found in relation to television radio, pamphlets and newspaper replicated in similar trends. ${ }^{14-16}$

\section{Knowledge concerning HIVIAIDS}

When students' knowledge is assessed using mean score, they generally seem to be knowledgeable about HIV/AIDS. However, closer examination of the frequency distribution manifested that students had substantial deficiencies in knowledge about HIV/AIDS in fundamental aspects. Only five students $(3.2 \%)$ answered the 18 questions correctly. The importance of abstinence from sex, consistent and correct use of condom, being faithful to one partner in the prevention of HIV infection were unrecognized by $17.9 \%, 14.7 \%$ and 
$35.7 \%$ respectively. Similarly, with regard to routes of transmission, having multiple sexual partner, mosquito bite, saliva and sweat, coughing \& sneezing sharing swimming pool were other areas where significant number of students shown lack of proper knowledge. Moreover, misconceptions had been seen on more than half of the students who claimed using double condom at once prevents HIV transmission better than single condom. This finding goes in agreement with Anahita's research conducted on Iranian students in 2004. This research revealed that only few students answered all knowledge questions presented correctly. Various research findings also illustrate the lower knowledge rates among young Africans and the need for further awareness program. ${ }^{17,18}$

\section{Attitude towards HIVIAIDS and PLWHAs}

When students' attitude is assessed using mean score, they generally seem to have a desirable attitude towards HIV/AIDS and PLWHAs. However, thorough examination of the frequency distribution revealed that almost half of the students had undesirable attitude towards HIV/AIDS and PLWHAs. This is highly strengthened by; out of 157 student participants only one student $(0.6 \%)$ had a complete desirable attitude for HIV/AIDS as well as PLWHAs. In harmony with the current finding, a study by Fethi ${ }^{19}$ revealed that Tunisian students attitude towards PWA was extremely negative. Similarly, Nwokochas' study showed that there was a defective attitude among Nigerian students towards HIV/AIDS and PLWHAs.

\section{Practice related to HIVIAIDS}

The result of the present study clearly manifested that the risk behaviors students had that would expose them for HIV. As depicted in Table 6 above more than one third of the study samples had sexual exposure and surprisingly from this figure $60.7 \%$ of them did the intercourse without using condom. Although HIV infection due to sharing of sharp materials is limited compared to the heterosexual transmission mode $36.9 \%$ of the respondents revealed that they had a habit of sharing sharp materials from other people. While it appears encouraging to note that more than half of the respondents chose to be abstinent from sex and 39.5\% seem faithful to their beloved ones, it is disturbing that only $8.3 \%$ of the respondents use condom consistently which may arisen from the misconception and undesirable attitude that HIV could not be prevented with the correct and consistent use of condom. Findings from other researchers have also confirmed the present report. ${ }^{6,20-22}$

\section{Gender and KAP related to HIVIAIDS}

One of the objectives of the present study was investigating whether there is statistically significant gender difference in knowledge, attitude, and practice score of male and female participants. Thus, the finding of the present study revealed that there was no a statistically significant gender difference in knowledge score of male and female students. In harmony with the present finding, a study by Marianne ${ }^{13}$ on knowledge of attitudes towards HIV/AIDS among post secondary students in southern Ethiopian city revealed that no significant difference in HIV knowledge scores between male and female students. Similarly, the cross-sectional study conducted by Marianne ${ }^{13}$ found no significant gender difference in HIV knowledge levels among South Africans residing in urban centers. Furthermore, the study conducted by Harding et al..$^{20}$ surveyed Nigerian university students regarding their HIV knowledge levels. The authors concluded gender was not a significant variable in determining HIV knowledge levels. Concerning students attitude score, the finding of the current study manifested that there was no a statistically significant gender difference between male and female participants. Inconsistent with the present finding a study by Nigatu \& Seman ${ }^{23}$ on attitudes and practice on HIV prevention among students of higher education in Ethiopia, the case of Addis Ababa University revealed that sex was found to be statistically significant factor for attitude on HIV/AIDS prevention. i.e., female respondents were found to be more likely to have favorable attitude on HIV prevention than their male counterparts. Though, it is difficult to give a confident explanation about the reason why such kind of inconsistencies were found between the previous and the present studies depending only on the present data, one possible explanation could be methodological differences between the previous and the present study. Differences in the cultural background of participants in the present study and the previous ones may also be the possible explanation.

Contrary to the above results, the finding of the present study manifested that a statistically significant gender difference was found in practice (sexual exposure, condom use, habit of sharing sharp materials) of male and female participants. Which is the mean score of males are higher than that of females; this implies that, male students were highly involved in sexual practice, less use of condom, share sharp materials with other individuals than that of their female counterparts. In harmony with this finding, one study in particular reviewed the sexual practices among high school students across four urban centers in Ethiopia. The study revealed that male students report higher risky behaviors such as multiple sexual partners and lower age of sexual debut in comparison to female students. ${ }^{13}$ Correspondingly, a cross-sectional study conducted among high school students found similar results, whereby male students were more likely to report a higher incidence of sexual activity in comparison to female students. ${ }^{13}$ Furthermore, according to the second round HIV/AIDS Behavioral Surveillance survey in Ethiopia, it was found out that around $9.9 \%$ of the in school youth (14.6\% of males and $5.3 \%$ of females) had sexual experience. ${ }^{5}$

\section{Year of study and KAP related to HIVIAIDS}

The finding of the current study also showed that a statistically significant difference was not found in the knowledge scores of participants among $1^{\text {st }}, 2^{\text {nd }}, \& 3^{\text {rd }}$ year students. Even if there was mean differences (i.e., the mean of 1st year students was higher than those of $2^{\text {nd }}$ and $3^{\text {rd }}$ year students the difference was not statistically significant. Inconsistent with the present finding a study by $\mathrm{Li}^{24}$ showed that inconsistent level of AIDS knowledge among students with significant grade level difference. Similarly, concerning attitude scores of the three year levels, even if the mean score of $1^{\text {st }}$ year students was higher than that of $2^{\text {nd }}$ and $3^{\text {rd }}$ year students plus the mean of $2^{\text {nd }}$ year students was higher than $3^{\text {rd }}$ year students, the mean difference was not statistically significant. Furthermore the finding revealed that a statistically significant difference was not found in participants practice scores among $1^{\text {st }}, 2^{\text {nd }}$, and $3^{\text {rd }}$ year students.

\section{Conclusions and recommendations}

The objective of this study was to examine HIV/AIDS related knowledge, attitude and practice among student-teachers of Hossana CTE. Accordingly, the following conclusions are made:

a. Majority (78.3\%) of Hosanna CTE students perceived the current status of HIV/AIDS in Ethiopia as a serious and very serious problem. 
b. Health professionals, television, radio, pamphlets, and teachers were the major sources of information for Hosanna CTE students to get knowledge about HIV/AIDS in a respective manner.

c. Since, the present finding revealed that a very few students $5(3.2 \%)$ answered all the knowledge questions correctly, it is seemingly possible to conclude that there was a huge knowledge gap among Hosanna CTE students with respect to routes of transmission and prevention mechanisms of HIV.

d. As the finding manifested, almost half of the students had undesirable attitude towards HIV/AIDS and PLWHAs. Moreover, only $1(0.6 \%)$ student had a complete desirable attitude towards HIV/AIDS and PLWHAs. Therefore it seems easy to conclude that students of Hosanna CTE had undesirable attitude towards HIV/AIDS and PLWHAs.

e. The finding showed that significant number of students $(35.7 \% 0)$ had sexual exposure with opposite sex, with the same vein, out of those students who had sexual experience majority of them did not used condom in the time of their sexual intercourse. Furthermore, $36.9 \%$ of the students had a habit of sharing sharp materials with other individuals that could expose them for HIV. Finally, with regard to students preferred preventive mechanisms, majority of them endorsed in abstinence and be faithful to one partner. Therefore, it can be concluded that Hosanna CTE students had risk behaviors which could expose them for HIV.

f. Gender could not have an influence on knowledge and attitude of students. However, gender had an influence on practices of students. That is male students had more sexual exposure, less condom use, and high sharing of sharp materials with other individuals than that of their female counterparts

g. Year of study did not influence students' knowledge, attitude, and practice about HIV/AIDS.

\section{Recommendations}

On the basis of the findings, the following recommendations were suggested.

College Anti-HIV/AIDS mainstreaming offices should design and implement college wide interventions activities that would alleviate the deficiencies and misconceptions observed with regard to knowledge about HIV/AIDS; intolerable and undesirable attitudes they had towards HIV/AIDS and PLWHAs respectively and risky behaviors that would expose them to HIV through:

i. Organize awareness creation and awareness raise workshops and panel discussions on HIV/AIDS and risky sexual behaviors

ii. Encouraging Voluntary Counseling Testing

iii. Preparing and disseminating contextualized pamphlets, posters, in relation to HIV/AIDS for free.

iv. carrying out free talk/conversation programs on issues related to HIV/AIDS

v. preparing college based HIV/AIDS manual

vi. preparing questions box for HIV/AIDS and other related issues

vii. giving training on proper condom usage

viii. presenting HIV/AIDS program on college mini media programs ix. inviting health professionals for in depth analysis about recent HIV/AIDS related issues

$\mathrm{x}$. Implementing Education and Training Institutions Community Conversation

xi. Since student-teachers knowledge, attitude and practice related to HIV/AIDS found to be unsatisfactory; the college's administration has to do the following

xii. Provide college wide sensitization and awareness raising trainings for all student-teachers

xiii. Allocate adequate amount of budget for the activities carried out by Anti-HIV/AIDS mainstreaming office

xiv. Give unreserved support, encouragement, fast facilitation in all necessary matters for the Anti-HIV/AIDS mainstreaming office.

\section{The College's teachers should}

a. Integrate HIV/AIDS related issues in their lesson delivery particularly teachers in the department of language, biology, psychology, civics and education.

b. Encourage students to be conversant about HIV/AIDS during and /or out of class hour with their teachers and among themselves.

c. Design instructional modules in manner responsive and sensitive to HIV/AIDS so that such actions could possibly address the gap currently exist and enhance student's deficiency in HIV/AIDS related KAP.

\section{Parents}

As the finding disclosed that most students did not get information about HIV/AIDS from their parents/guardians. This might be because, in most Ethiopian culture, talking about sexual matters considered as taboo or make the first move to sexual desire. However, whether they like it or not, children would get knowledge about sex and their sexuality from other sources particularly from peers probably wrongly. If so, it is good for parents to have free discussion with their children when they are ready to understand the issue. In such a way they can protect children from consequences arise from misconception or lack of knowledge; wrong attitude or improper practices.

\section{The college's gender mainstreaming office}

Since the finding of the study revealed that female students found to be more prone to HIV infection than their counterparts, the office need to work in hand to hand cooperation with Anti-HIV/AIDS Mainstreaming office in helping female students to be more assertive through provision of continuous life skills trainings.

\section{Acknowledgments}

None.

\section{Conflicts of interest}

The authors declare that there is no conflict of interest.

\section{References}

1. Fishbein M. The role of theory in HIV prevention. AIDS care. 2000;12(3):273-278.

2. UNAIDS/WHO. AIDS epidemic update UNAIDS 20 avenues Appia CH-1211 Geneva 27 Switzerland. 2009. 
3. WHO \& UNAIDS. AIDS Epidemic Update. 2006.

4. USAID. HIV/AIDS Health Profile for Ethiopia. AA. Ethioipia. 2010.

5. Behavioral Surveillance Survey (BSS) Ethiopia. Round Two, MOH/ HAPCO, AAU, CSA, EPHA, Addis Ababa, Ethiopia. 2005.

6. UNAIDS. Report of the Meeting of the UNAIDS Reference Group on HIV Prevention. Glion, Switzerland UNAIDS annual report 2002. 2005.

7. Abdinasir A, Gurja B, Sentayehu T. Knowledge, Attitude, Practice and Behavior (KAPB) Survey on HIV/AIDS among AAU Students. $A A U$, Ethiopia: UNFPA, ISAPSO. 2002.

8. Elias Worku. Internet -Based Technology as source of sexual and HIV/ AIDS Related Health Information among AAU students. Unpublished Thesis. 2009

9. Getnet T. Self reported sexual experiences, sexual conduct and safer sex practices of AAU undergraduate male and female student's on the context of HIV/AIDS pandemics. A PhD dissertation the State University of New York at Buffalo, USA. 2009

10. Teka T. College Students' Attitude and knowledge of AIDS. Ethiopia Med. J. 1993;31(4):233-237.

11. Tefera B, Challi J, Yoseph M. KAP about HIV/AIDS, VCT Among students of Jimma University, Jimma Zone, SW, Ethiopia. J Health Sci. $2004 ; 14$.

12. Beyene P, Solomon B, Yared M. AIDS and college Students in Addis Ababa: A Study of Knowledge, Attitude and Behavior. Ethiop J Health Dev. 1997;11(2):20-30.

13. Marianne M. The knowledge of and attitudes towards HIV/ AIDS among post-secondary students in a southern Ethiopian city. Unpublished MA thesis McMaster University. 2011.

14. Champ, Partner. AIDS related knowledge, Attitudes, Behavior and practices: a survey of 6 Chinese cities. Health. 2008.
15. Anahita Tavoosi. Knowledge and attitude towards HIV/AIDS among Iranian students. BMC Public Health. 2004;4(1):17.

16. Shiferaw. Assessment of knowledge, attitude and risk behavior towards HIV/AIDS and other sexual transmitted infection among preparatory students of Gondar town. North West Ethiopia. 2011;4:505.

17. Buseh AG, Glass L, Mc Elmurry J, et al. Primary and preferred sources of HIV/AIDS and sexual risk behavior information among adolescents in Swaziland, Southern Africa. International Journal of Nursing Studies. 2001;39(5):525-538

18. Negash Y, Gebre B, Benti D, et al. A community based study on knowledge, attitude and practice (KAP) on HIV/AIDS in Gambella town, Western Ethiopia. Ethiopian Journal of Health Development. 2003;17(3):205-215

19. Fethi Tebourski. Knowledge and attitudes of high school students regarding HIV/AIDS in Tunisia: does more knowledge lead to more positive attitudes? J Adolesc Health. 2004;34(3):161-162.

20. Harding AK. Nigerian university students' knowledge, perceptions, and behaviors about HIV/AIDS: are these students at risk? JR Soc Health Mar. 1999;119(1):23-31.

21. Babikian T. An Assessment of HIV/AIDS Risk in Higher Education Students in Yerevan, Armenia. AIDS and Behavior. 2004;8(1):47-61.

22. Gurman T. Condom use among Latino College students. J Am Coll Health. 2004;52(4):169-78.

23. Nigatu R, Seman K. Attitudes and Practices on HIV Preventions among Students of Higher Education Institutions in Ethiopia. International Research Journal. 2011;8(2):828-840.

24. Li X. HIV/AIDS knowledge and the implications for health promotion programs among Chinese college students: geographic, gender and age differences. Health Promotion International. 2004;19(3):345-356. 